The first edition of this book appeared in 1950 and was a valuable manual for works' managers and those involved in supervision of the handling of toxic materials in industry. In the preface to this edition it is pointed out that standards of permissible concentrations of toxic substances have found increasing acceptance and have become more severe. Also, many new analytical methods have been developed over the past decade, with particular emphasis on the analysis of body fluids. The author claims to have made an attempt to include the more important of these new developments, but seems to have been more successful in gathering toxicological data than analytical methods.

The layout of the book is good with a comprehensive chapter on air-sampling devices and discussion of their practical advantages and disadvantages. Chapters are devoted as before to the elements, inorganic compounds, different classes of organic compounds, and natural and industrial products. Toxicity data have been brought up to date and the bibliography increased accordingly. There is a new chapter on radioactive isotopes and increased information on the chlorinated hydrocarbon and organophosphorus insecticides.

The chief disappointment is in the almost unchanged section on analytical methods where little notice seems to have been taken of the new techniques referred to in the preface. Many of the methods are unspecific, as, for instance, those for chlorinated hydrocarbons by alkaline hydrolysis and titration; this is a pity, as the toxicity of a solvent may well depend on the amount of a related impurity present. Little advance has been made in the use of colorimetric methods which, besides being often quick and specific, are peculiarly suited to the analysis of multiple samples. Several of the colorimetric methods retained from the first edition still irritate by instructing the worker to "read through a No.-filter"; may we not have the wavelength of maximum adsorption given also? New alternative methods are given for cyanide and formaldehyde and there are methods for two or three compounds in urine not previously listed, besides methods for uranium, plutonium, radium, and strontium 90 . There is only one example given for mixed toxic materials, that for benzene and toluene in air. Headings in Tables 41, 42,43 , and 46 are confusing, and Table 51 states no units of volume.

Both type and page size have been increased; this has not improved legibility but may have contributed to the doubling of the price from $44 s$. to $92 s$.

\section{K. JOHNSON}

De Industriele Loodintoxicatie in Nederland. By $R$. L. Zeilhuis. (Pp. 271; 46 figures, 45 tables, English summary of 5 pp.) Leiden: N. V. Drukkerij $\mathrm{V} / \mathrm{H}$ Batteljee and Terpstra. 1959.

The author finds lead the commonest industrial poison in the Netherlands and discusses the complex nature of varying types of industrial exposure. He finds battery manufacture and the making of certain pigments to be associated with considerable risk while he remarks on the comparative freedom of painters and printers from lead trouble. Preventive action must not await symptoms and the level of absorption should never be sufficient to produce these. The author finds punctate basophilia, the increase in the reticulocyte count and the rise in urinary coproporphyrins to be the most valuable indices of intoxication. The lead content of urine or blood provides less information about the reaction of the organism to the poison though it may give a precise measure of the level of absorption. Furthermore, the difficulty of the methods makes them unsuitable for routine screening of large industrial populations.

$\mathrm{He}$ concludes that of the various laboratory control methods punctate basophilia, as estimated by a dark ground technique, is a reliable method, while increased urinary coproporphyrin is an early sign of increased lead intake but is not such a reliable index of the extent of any subsequent increase. He regards a fall in haemoglobin as likely to be associated with increased "exposure intensity".

The author maintains that his investigations show that the MAC should certainly not be raised above $0.15 \mathrm{mg}$. per c.m. He wisely emphasizes the danger of distributing Ca EDTA as a prophylactic measure. Such practice he regards as quite unjustifiable; prophylaxis depends on good hygiene.

This is a sound, honest, and practical study of the lead industry of the Netherlands. It has been carried out with care and with common sense and even for those who, like the reviewer, have to rely on the English summary there is much to be learned about the supervision of the workman in the lead industries.

\section{R. E. LANE}

Exploration in Group Relations. By E. L. Trist and C. Sofer. (Pp. 64. 7s. 6d.) Leicester University Press. 1959.

This is a report of the first full-scale experiment in Britain with the "laboratory" method of training in group relations, the conference held in September, 1957, by the University of Leicester and the Tavistock Institute of Human Relations. Members of the Conference included a wide variety of those whose work brings them into close contact with such problems, as personnel managers, labour officers, probation officers, teachers, and wardens of educational establishments, and even prison governors. The methods used were based on those pioneered by the National Training Laboratory in Group Development at Bethel, Maine, and its allied institutions in the United States; that is to say, on small leaderless study groups of six to 12 members each with a consultant and an observer, similarly organized application groups, which (unlike the former) were given specific projects, and concurrent lectures and tutorials on social theory. All staff were professional psychologists or social scientists and those who conducted the study groups were psychoanalytically trained.

Although the British version of Bethel does not seem to have reached the emotional, "palsy-walsy", confessional heights of the sessions in the parent body; one does not hear, for example, that the group members' place cards were labelled in large letters with such abbreviated first names as "Joe", "Pru", "Herb", or "Bill", nor that 
they were wont to sing in the dining-room the soulstirring couplet:

"In S-groups we will bare our souls;

In A-groups we will play our roles."

They appear, nevertheless, to have exhibited the appropriate group and individual emotional responses. One hopes that their abreactions were equalled by their insight.

Such methods are doubtless significant and useful in research. But from the point of view of training of management in industry it is necessary to consider them from other standpoints and ask such questions as: (1) What are the practical results of such training, and is the period (12 days in this case) long enough? (2) Do the results justify the cost, which at Leicester was $£ 125$ per person excluding certain additional costs borne by the University? (3) Does a too-exclusive concern with the once neglected emotional reactions of the primary face-to-face working group lead to disregard of the equally important problem of rational, formal organization in a business concern?

We are willing to accept Elton Mayo's demonstration that a collection of mature adults may form a very immature working group but is it adequately realized that a collection of mature working groups brought up in the best traditions of "human relations in industry" may, in the absence of adequate organization, form a grossly inefficient factory or industry?

\section{J. A. C. Brown}

\section{BOOKS RECEIVED}

(Review in a later issue is not precluded by notice here of books received.)

Report on the Health of the Royal Air Force and Women's Services of the Royal Air Force for the Year 1955. Promulgated by Command of the Air Council (A.P. 3319/55). (Pp. 88; 9 figures.) London: Air Ministry. 1959.

International Directory of Institutions Engaged in Study, Research and Other Activities in the Field of Occupational Safety and Health, Volumes I and II [English edition.] Loose-leaf. Geneva: International Labour Office. 1958.

Acoustics Noise and Buildings. By P. H. Parkin and W. R. Humphreys. (Pp. 331 ; illustrated. 70s.) London: Faber \& Faber. 1958.

Venture to the Arctic. (British North Greenland Expedition). Edited by R. A. Hamilton. (Pp. xiv + 273 + Index; 38 figures. 5s.). Harmondsworth, Middlesex: Penguin Books. 1958.

Expert Committee on Training of Health Personnel in Health Education of the Public. [Wld Hlth Org. techn. Rep. Ser. No. 156.] (Pp. 39. 1s. 9d.) London: H.M.S.O.; Geneva. World Health Organization. 1958.

Bericht über das Gesundheitswesen in Österreich in Jahre 1957. (Pp. 160; 36 tables. \$5.50.) Vienna: Republik Österreich Bundersministerium für Soziale Verwatling. 1958.
Empire Rheumatism Council Twenty-Second Annual Report 1958. (Pp. 50; 5 figures.) London: 1959.

Smoking and Lung Cancer. By T. W. Lees. (Pp. 32; 2 figures.) Carluke, Lanarkshire: Law Hospital. 1959.

Manuale di Medicina del Lavoro, 2nd ed. By F. Molfino. (Pp. 890. Lire 10,000.) Torino: Edizone Minerva Medica.

Perspectives in Virology: A Symposium. Edited by Morris Pollard. (Pp. xix +312 ; illustrated. 56s.) London: Chapman \& Hall; New York: John Wiley. 1959.

Medical Education: Annotated Bibliography 19461955. (Pp. 391. 35s.) London: H.M.S.O.; Geneva: World Health Organization. 1958.

What is Cybernetics? By G. T. Giulbaud; translated by Valerie MacKay. (Pp. viii +126 ; 26 figures. 10s. 6d.) London: Heinemann. 1959.

Hypertension and Coronary Heart Diseases: Classification and Criteria for Epidemiological Studies. First Report of the Expert Committee on Cardiovascular Diseases and Hypertension. [Wld Hlth Org. techn. Rep. Ser. No. 168.] (Pp. 28. 1s. 9d.) London: H.M.S.O.; Geneva: World Health Organization. 1959.

A Synopsis of Skin Diseases. By Bethal E. R. Solomons, Jr. (Pp. 304; 14 figures. 30s.) Bristol: John Wright. 1959.

Smoking: The Cancer Controversy. By Sir Ronald A. Fisher. (Pp. 47. 2s. 6d.) Edinburgh and London: Oliver \& Boyd. 1959.

Statistics of Smoking, 2nd ed. Tobacco Manufacturers' Standing Committee Research Papers No. 1. Edited by G. F. Todd. (Pp. 81 f'scap.) London: CampbellJohnson. 1959.

Air Pollution Control. By W. L. Faith. (Pp. vii + 259; illustrated. 68s.) London: Chapman \& Hall; New York: John Wiley. 1959.

Central Mining-Rand Mines Group Report for the Year 1958. By A. M. Coetzee, Chief Medical Officer. (Pp. 24; 1 chart.) 1959.

Sonderausschuss Radioaktivitat: Bundesrepublik Deutschland, 2nd ed. (Pp. 117; 8 figures +60 tables. DM 12.60.) Stuttgart: Georg Thieme. 1959.

La Tuberculose des Houilleurs. By Jaques Prignot. (Pp. 327; 42 figures.) Brussels: Éditions Arscia. 1959.

Preventive Medicine: Principles of Prevention in the Occurrence and Progression of Disease. By H. E. Hilleboe and J. W. Larimore. (Pp. xxi + 731; 59 figures. 84s.) Philadelphia and London: W. B. Saunders. 1959.

Fire Research 1958. Report of the Fire Research Board with the Report of the Director of Fire Research. (Pp. vi $+54 ; 21$ figures +8 plates. 5s.) London: Department of Scientific and Industrial Research. 1959.

British Steel Castings Research Association: Sixth Annual Report, 1959. (Pp. 28; illustrated.) Sheffield. 1959. 